\title{
Creative destruction? Cases of defence conversion in the United States
}

\author{
C. Preble \\ Defense and Foreign Policy Studies, The Cato Institute, USA
}

\begin{abstract}
Politicians often claim that the closure of military facilities will do irreparable harm to local economies. Such predictions can be refuted by empirical data, and by studying actual cases of defence conversion in the United States. This paper considers the economic impact of the closure, and subsequent redevelopment efforts, of three facilities: Bergstrom Air Force Base in Austin, Texas; DuPont's Eleutherian Mills in Wilmington, Delaware; and the Brooklyn Navy Yard in New York. It is reasonable to infer from this research, when combined with aggregate empirical data, that defence conversion often generates greater economic activity than prevailed before the closures.

Keywords: defence economics, Brooklyn Navy Yard, Bergstrom Air Force Base, Eleutherian Mills, Hagley, DuPont.
\end{abstract}

\section{Introduction}

Industry leaders and politicians regularly claim that the closure of military facilities will do irreparable harm to local economies. Such predictions of certain calamity can be refuted by empirical data, and by a careful study of actual cases of defence conversion. In general, there are clear societal and economic benefits associated with moving resources from the military to more productive industry sectors, and to civilian uses. We take such resource shifts for granted in the private sector, when changing consumer tastes and new technologies cause some businesses to fail while others thrive. But politics and parochialism often intrude when military needs change. Instead of imagining the jobs lost when military bases close, or when military manufacturers relocate or retool, this paper will present several cases of defence conversion in the United States from the 19th, 20th, and 21 st centuries. Although the record is mixed, most localities did eventually 
recover, with many seeing higher employment, and greater economic activity, than prevailed before the closures. The paper will conclude with some observations about why some places fared better than others, and offer policy recommendations for those confronting additional defense industry consolidation driven by fiscal austerity and the evolving security environment.

\section{Contemporary perceptions of military spending cuts}

In the summer of 2012, industry leaders and politicians rushed to the ramparts to fend off cuts in military spending. They claimed that sequestration - the automatic, across-the-board spending cuts initiated by the failure of Congress and the White House to agree on a deficit reduction package the previous year - would undermine U.S. security and harm the nation's fragile economy.

Such assertions about the national security implications of these cuts cannot be tested, even in retrospect. If war comes, many will claim that reductions in military spending invited foreign aggression, or prevented the United States from intervening in a small conflict before it became a big one. But they cannot prove that that is the case; history cannot be replayed.

But the claims of grave economic harm are easier to scrutinize. In particular, the most dire predictions - for example, that more than 1 million Americans would lose their jobs due to the defence cuts under sequestration [1] - drew criticism from a number of economists, including Barro and de Rugy [2], and Zycher [3]. These critiques focused on the dubious methodology, particularly the use of a grossly inflated Keynesian multiplier.

But there is also a more theoretical argument at work: studies purporting to show the grave economic harm caused by military spending cuts tend to ignore the beneficial effects that will flow, eventually, by moving resources from the less productive military sector to the more productive private sector.

We take such resource shifts for granted when it pertains to changing consumer tastes, even if we are sometimes sad or inconvenienced when some of our favourite stores or brands succumb to competitive pressure. As an undergraduate, I spent a good amount of my time, and what little money I had, at Tower Records. Tower is no more, undone by the move to digital media, .mp3 files and now Apple iTunes. My favourite bookstore, Borders, is also gone. It couldn't compete with Amazon, first the inexpensive books delivered by mail in a few days, now the Kindle which delivers even cheaper books instantly.

Military technologies also evolve over time, from men carrying weapons into battle, to horses, and later tanks and trucks, carrying men. Manned aircraft once dropped bombs. Now unmanned aircraft fire missiles. Machine guns replaced boltaction rifles, which, in turn, had replaced smoothbore, muzzle loading muskets. Steam power replaced sails in ships. The engines today burn petroleum derivatives, whereas they had once relied on coal. Someday they might burn biofuels, or nothing at all.

We've also seen the decline of war, in general. This has contributed to lower military spending in the aggregate, especially in places that were once prone to persistent bouts of violent conflict, but which have since settled into long periods 
of peace. The castles and walled cities of Europe once provided protection from foreign invaders. Now they provide an invitation for foreign tourists to visit. Dozens of cities and towns scattered throughout the United States began as military outposts. Now only their names (Fort Lauderdale and Fort Lee, Fort Wayne and Fort Worth) remind us of their original purpose.

Changing consumer preferences and needs (i.e. demand) affect the supply of particular products and services. In much the same way, technological and geopolitical change affects both the demand for military hardware, and ultimately its character. We are buying fewer ships today than we did a generation ago, and we're buying different kinds of ships. Jet-powered aircraft have replaced propeller-driven ones, just as monoplanes replaced biplanes in an earlier era. The manufacturers of ships and planes, therefore, have constantly had to adapt. And those that haven't have simply disappeared.

When businesses close, the communities around them must also adapt. Their populations shift as people leave in search of opportunities elsewhere. Those who remain must find new jobs to replace those lost. Civic leaders must find new sources of tax revenue. Some communities do relatively well, others do not.

This paper highlights the local economic changes associated with the closure of Bergstrom Air Force Base in Austin, Texas; DuPont's Eleutherian Mills in Wilmington, Delaware; and the Brooklyn Navy Yard in New York. It considers the economics of defence conversion, but focuses mainly on the political, social, and cultural aspects. These are stories about the nuts and bolts of business, and sometimes about how politics distorts business practices. But they are also stories about people and their livelihoods, and thus oftentimes intensely personal.

\section{Past perceptions of military spending cuts}

The object is to reframe the French essayist Frederic Bastiat's "The Demobilization," written in 1848 , for the 21 st century. Bastiat complained that people inevitably focus on "the seen" of lost jobs, abandoned factories, and unused land. But it is equally important to take account of the unseen effects, of how a change in the international system (in terms of diminished threats), and the evolution of technology (that enables us to deter or resolve those threats with fewer resources) is beneficial for the economy, and society as a whole.

Discharging soldiers from active duty, for example, can be a good thing - both for the soldiers, and for the taxpayers who pay their salaries. Consider the case from the beginning: a new soldier is recruited for active duty. At first glance, it might appear that the productive activity is simply moving from one town to another. In that case, the economy as a whole doesn't suffer.

But, as Bastiat explained in 1848, "In the village a man dug and labored: he was a worker; at Metz [the French equivalent to Fort Sill today] he goes through "Right dress!" and "Left dress!": he is a soldier. The money involved and its circulation are the same in both cases: but in one there were three hundred days of productive labor; in the other there are three hundred days of unproductive labor, on the supposition, of course, that a part of the army is not indispensable to public security." 
Then Bastiat turned the argument around. If we are to avoid discharging some number of soldiers after a war is concluded, and they are no longer needed for national security, out of fear that their demobilization will increase the unemployment rate, or lower wages and living standards for those already employed, "If," in other words, as Bastiat wrote, "all things considered, there is a national profit in increasing the size of the army, why not call the whole...population of the country to the colors?" [4].

History provides a useful guide for what has actually happened in the past when military spending declines, and the defence industry contracts. We can look at periods after major drawdowns - after World War II, after Korea, and after the end of the Cold War - and find no correlation between military spending and GDP. If anything, some of the periods in which defence spending declined most dramatically coincide with some of the periods of greatest economic growth in U.S. history: the-late 1940s (Henderson [5]), and the 1990s.

\section{Arranging and classifying the cases}

These aggregate statistics only tell part of a story, however. This paper will drill down to explore a few communities.

At that level, we can observe what former military bases are used for today, if at all. We can revisit former factories. Have those properties been put to other uses? Or do they sit unused, crumbling, monstrosities blighting the landscape?

I have begun to assemble short stories on more than 20 different military facilities, many of them former bases, but also some particular factories or firms once heavily involved in supplying material and equipment to the military. Before discussing the individual cases previously mentioned, three general types of transition must be discussed: relative decline; technological change; and calculated consolidation.

\subsection{Relative decline}

In some cases, the growth of other industries steadily supplants the military as the dominant player. It is not that military spending in a particular place has declined precipitously, or per se, but rather that it hasn't grown as fast as other industries. The San Diego area fits this category. San Diego still boasts a large military presence - including a huge naval base, and two major Marine Corps installations - but military spending as a whole accounts for a smaller share of the region's economic activity than 20 years ago.

One could guess that this has happened in many different communities around the United States given that military spending averaged 10.4 percent of GDP during the 1950s, and 7.4 percent during the entire Cold War period (1949-1991). It now accounts for about 4.5 percent, and is expected to decline to less than 3 percent of GDP by the end of the decade.

If that is true in the aggregate at the national level, then it is certainly true in many individual cases, and at the regional and local level. Simply put, the military accounts for a small and shrinking share of economic activity, including in those 
communities or regions that are still relatively more dependent on it than the nation as a whole.

\subsection{Technological change: adapt or die}

A second type of transition is more analogous to those seen in consumer brands, and in non-military businesses in general: the gradual replacement of now-obscure military technology or materials with newer ones. Saddles, muzzle-loading muskets, bolt-action rifles, sails, steam turbines, canned K-Rations. The list goes on. These types of cases are more akin to Borders and Tower Records (or typewriter repair) discussed above. No one person is responsible for the collapse of those businesses. But politics intrudes when it comes to public expenditures, delaying or impeding the creative destruction process in the short-term interest of preserving jobs in the distressed industry.

Meanwhile, some companies anticipate changing technologies, and adapt or diversify to become stronger than they were before. For example, in one of the cases detailed in this chapter, the E. I. du Pont de Nemours \& Company once operated the world's largest black powder mill on the banks of the Brandywine River in Wilmington, Delaware. By the turn of the 20th century, however, the world's militaries had begun shifting to smokeless powder, and in 1921 DuPont shuttered its black powder operations.

But while the mill ceased to exist, DuPont thrived, and with it the entire city of Wilmington. The company established the DuPont Experimental Station on lands once occupied by the original powder mill. Some of the most important discoveries in modern chemistry have occurred in these labs. And DuPont itself is still one of largest employers in the city, and the entire region. The company continues to sell to the military, but such sales today account for only a tiny share of DuPont's total business.

\subsection{Calculated consolidation}

A third type of case flows from a conscious decision to consolidate or close a facility because it is no longer needed. Unlike the first two cases, such calculated consolidation invites strong opposition, so much so, in fact, that an entire mechanism was created to insulate decision makers from political backlash: the Base Realignment and Closure (BRAC) process.

The state of Maine in the north-eastern United States hosted two bases that played an important role during the Cold War: Loring Air Force Base and Brunswick Naval Air Station. Both were deemed superfluous during the BRAC process given the end of the Cold War (the threat changed; demand declined) and new technology (satellites and small, sea-based aircraft supplanted large, manned aircraft - in this case the P-3 Orion). Base closures and other forms of calculated consolidation attract more attention than the other two cases, because they are particularly susceptible to political manipulation. But they are certainly not the only type, and they involve some aspects of the other cases (esp. technological change). Meanwhile, the admittedly subjective assessment of evolving threats paves the way for some to argue that the underlying strategic rationale is also 
misguided (i.e. that the capacity being reduced is still needed; that the demand remains very high).

\section{The cases}

The following section highlights three cases of defence conversion: Bergstrom Air Force Base in Austin, Texas, an example of relative decline; DuPont's Eleutherian Mills in Wilmington, Delaware, a case of technological change; and the Brooklyn Navy Yard in New York, an instance of calculated consolidation.

\subsection{Bergstrom Air Force Base, Austin, Texas}

In the mid- to late-1980s, the city of Austin, Texas had a problem. Its Robert Mueller Municipal Airport was completely inadequate. Constructed at a time when Austin was known for being the state capital and the home of the University of Texas, and not much else, Mueller could accommodate a few flights daily, nearly all of them small planes routing through larger hub airports in Dallas-Fort Worth and Houston. Those planes flying into Mueller had to approach at a steep angle, descending over Interstate-35. Those taking off had to contend with what pilots and air traffic controllers called a SNAFU intersection - the risk of a midair collision with the U.S. military planes taking off from nearby Bergstrom Air Force Base.

A quaint regional airport might have been sufficient if Austin continued along its gentle trajectory from the 1970s. But boom times came in 1983, and, not long after, so did a common complaint: Mueller had to go.

It all started when Bobby Ray Inman, the legendary naval admiral and tech guru, partnered with the state of Texas and the University of Texas to form the MCC tech consortium. Almost overnight, the culture in Austin was transformed. Money flowed to university researchers experimenting with cutting-edge computer technologies like the semiconductor and personal computers. Then, in 1988, Michael Dell, UT's most famous drop out, took his personal computer company public. By the early 1990s, the business that he had started in his dorm room was employing tens of thousands in the city of Austin and its environs.

All this activity caught the attention of tech firm investors and venture capitalists, who descended on Austin like grasshoppers. They arrived at Mueller airport, and made their way to UT and state government offices through some of Austin's poorest neighbourhoods, mostly African-Americans consigned to undesirable real estate in Mueller's noisy flight path during Austin's segregated days. City fathers (they were mostly men then) and state officials realized they weren't putting their best foot forward. Thus the search began for a new airport.

The job fell to Pike Powers, a former state legislator, and chief of staff to Texas Governor Mark White. In January 1984, Austin Mayor Ron Mullen tapped Powers to chair the Austin Citizens' Airport Task Force. Airline industry executives counselled Powers not to go overboard on the design for the new airport. Powers recalled American Airline's Robert Crandall getting "right in my face" in a meeting to discuss plans for the new airport. "We don't want a Taj Mahal," Powers 
recalled him saying, meaning an unnecessarily costly airport that would so saddle passengers with fees and taxes that they wouldn't want to fly there [6]. Southwest's Herb Kelleher agreed [7].

Given concerns about costs and capacity, Powers and others proposed using a portion of the sprawling Bergstrom Air Force base for commercial flights. Such dual-use arrangements were rare, but not unprecedented. But despite the Air Force's frustration with Mueller and SNAFU intersection, they turned aside Austin's pleas. Not even the legendary Congressman J.J. "Jake" Pickle could convince the Air Force to relent.

But Bergstrom wound up on the Base Realignment and Closure Commission's list in July 1991, and within a few years the base reverted to the city that had loaned the land to the U.S. Army during World War II. Construction on a new civilian airport there began on March 6, 1995, and the airport opened to the public on May 23, 1999 [8]. It cost $\$ 585$ million, financed by a surtax on travellers, but few complained. Those costs were recouped within a decade. In 2012, more than 9.4 million travellers came through the shining facility that features local cuisine and live music.

The question of how the community would adjust to the loss of Bergstrom Air Force Base was never seriously at issue. Veteran newsman Kirk Ladendorf, who had arrived in Austin in 1981, recalled years later that "it was a natural" to close Bergstrom. Base closures could be devastating for many surrounding communities, but "frankly, we hardly even noticed. We were going so strong it was hard to see any measurable impact" [9].

\subsection{DuPont's Eleutherian Mills, Wilmington, Delaware}

In the summer of 1802, Eleuthère Irénée (E. I.) du Pont established along the banks of the Brandywine River, about five miles north of Wilmington, Delaware, a series of mills for producing black powder. The company he founded, E. I. du Pont de Nemours \& Company, continued making gunpowder, and other explosives, in and around that same location for more than 120 years. And, along the way, DuPont, as it is known by most, would become one of the largest and most profitable corporations in the world.

E. I. had studied chemistry in France, and had been planning since his late teens to work at the French government's national Powder and Saltpeter Administration. The family fled France to escape the reign of terror in late 1799, but within a year after arriving in the new United States, E. I. had completed his survey of the young country's gunpowder manufacturers. He was confident that he could produce a superior product, and turn a tidy profit, and after traveling to France to raise funds for the venture, he returned to the United States with an eye to establishing operations in the Wilmington area [10].

The Brandywine River was perfectly suited for the task. It flowed strongly enough, in both the dry summer and the cold winter, to power mills. It was located close enough to the navigable Delaware River to ensure steady delivery to a wide market of consumers, but far enough away from the distractions in the city of Wilmington that might lure away workers. E. I. purchased 65 acres of land on the banks of the Brandywine in 1802, and began constructing what came to be known 
as the Eleutherian Mills. He started by manufacturing saltpeter, one of the critical ingredients for gunpowder, which before that time could only be obtained from British-controlled India. Unsurprisingly, one of his first big sales was to the U.S. government. Within another year, E. I. was manufacturing gunpowder, marketed as "Brandywine Powder."

It was a hit, favored for its high quality and reliability. Over the next several decades, the company sold gunpowder to the U.S. government during the Wars of 1812 and the Mexican-American War. Its first overseas export was to the government of Spain in 1805. In the 1830s, France and England purchased DuPont powder to wage the Crimean War. But explosive powder was also needed along the frontier to clear tree stumps and shoot game. The canal construction of the 1820 s and 1830 s relied on explosives to blast away rocks. The railroad boom that followed used black powder to cut and grade embankments. DuPont blasting powder was later used in the coal mines of eastern Pennsylvania. California's Gold Rush boosted demand, too. Between 1850 and 1855, company sales grew at an average of 22 percent per year.

The company expanded to meet the demand, creeping along the banks of the Brandywine River. The most significant expansions usually coincided with war, or the prospect of one. For example, in 1812, anticipating greater demand for his product in the coming war with England, E. I. acquired the "Hagley", a farm just downstream from the original Eleutherian Mills. Increased domestic demand along with orders from the U.S. government during the Mexican-American War, prompted yet another expansion down river, to a site that became known as the Lower Yards. Scientific American declared in 1850 that DuPont's powder mills were "the most extensive... in the world" [10].

E. I.'s grandson, Lammot, an accomplished chemist, capitalized on his skills to grow the family business. In 1857 , he perfected a new method for refining sodium nitrate, lowering manufacturing costs, and reducing the company's dependence upon potassium nitrate from British India [10]. Then, in the $1880 \mathrm{~s}$, he convinced his family members and business partners to add dynamite to the company's product line. The trouble was that dynamite was harder to produce, and relied upon a sophisticated knowledge of chemistry, more sophisticated, at least, than black powder [11]. Accordingly, in 1902, DuPont's subsidiary the Eastern Dynamite Company, established Eastern Laboratory, the first facility formally dedicated to research and development. The lab had no immediate manufacturing responsibilities, and was focused instead on the "specific mission to improve the company's high explosive products and processes through scientific research and development" [11].

One year later, in 1903, the company established a second research facility just across the Brandywine River from the 100-year-old black powder mills. Known as the Experimental Station, that lab's mission quickly became even more ambitious than its cousin. It began as a testing way-station for new products being pitched to DuPont, hence the name. Within a few years, however, it became a fullfledged research laboratory. DuPont's main customers, the U.S. Army and Navy, were under pressure to develop their own research capabilities, and to achieve and maintain an innovative edge over future potential adversaries. By rededicating the 
Experimental Station to basic research, and not just testing, DuPont effectively became the Army and Navy's main R\&D arm, developing and perfecting high explosives, including black powder, dynamite, and the emerging successor to black powder, smokeless powder [11].

The company never looked back on that decision, investing heavily in R\&D over the years, and becoming a leader in chemistry, the life sciences, and a host of other scientific pursuits. It's most important products over the years have included cellophane, neoprene, nylon, Teflon, Tyvek and Kevlar. By the early 1980s, DuPont's research budget topped $\$ 1$ billion on sales of $\$ 30$ billion [11]. In 2013, the company invested $\$ 2.2$ billion to $R \& D$ on net sales of $\$ 35.7$ billion, and it employs more than 10,000 scientists and engineers worldwide [12].

But while DuPont's commitment to innovation and research never stopped, the mills along the Brandywine River did, grinding to a halt in the early 1920s. Less than a quarter century after the DuPont company's executives had decided that they needed dedicated laboratories to perfect the company's processes for making powder, dynamite, and other explosives and instruments of war, the company stopped making black powder.

DuPont's importance in the greater Wilmington area, and in the wider region, is hard to exaggerate. It is the largest private employer in the state of Delaware, and in 2014 ranked 86th in the Fortune 500's annual list of the top U.S. corporations [13]. The end of E. I.'s black powder business obviously didn't signal the end of his company's business. If anything, it appears to have been the spark that launched the company into a century of successful innovation.

\subsection{Brooklyn Navy Yard, Brooklyn, New York}

Some of the most famous ships in the history of the U.S. Navy launched from the Brooklyn Navy Yard.

During the American Civil War, the USS Monitor was outfitted with its famous turret and guns in the Yard. So too the battleship Maine, whose destruction in Havana Harbor in February 1898 became a rallying cry ("Remember the Maine") for the Spanish-American War. The battleship Arizona, launched from Brooklyn in 1916, was tied to a pier on Ford Island, Pearl Harbor, Hawaii, at 0800 on December 7, 1941, when four Japanese bombs struck it amidships and astern. The ship still rests where she sank that day, portions of one turret protruding above the surface. More than 1 million people visit the USS Arizona Memorial every year.

Other ships built in the yard enjoyed a happier fate. The battleship Missouri served as the scene of the Japanese surrender in World War II, and now sits anchored a few hundred feet from the Arizona in Pearl Harbor, book ends symbolizing the beginning and the end of the United States' deadliest foreign war. And both started at Brooklyn Navy Yard.

But in the decades following World War II, the Yard's own name was less a mark of pride than a source of shame. One of more than 100 military facilities designated for closure in 1964, the Yard's 300 acres were largely abandoned through most of the 1970s and 80s, becoming "a symbol of government disinvestment, the decline of large-scale manufacturing, and urban decay" [14]. 
Situated between the Manhattan and Williamsburg Bridges on the East River located in what is now known as Brooklyn's Dumbo District (Down Under Manhattan Bridge), the Yard was an incredible scene during its heyday in World War II. The sights and sounds of a massive war machine filled the air day and night, with over 70,000 people working in three shifts, seven days a week [15].

Yet, as after prior conflicts, demand for the Yard's services plunged when the guns of war fell silent. The Yard's total workforce dipped below 10,000 in 1949. By the early 1960s, employment at the Yard had fallen to Depression Era levels. Secretary of Defense Robert McNamara sounded the death knell on November 20, 1964: the Brooklyn Navy Yard would be closed in 1966, along with nearly 100 other bases and defense facilities [15].

The City of New York took control of the site, but its many efforts to transform the Yard into a private industrial park failed. A not-for-profit corporation Commerce, Labor, Industry in County of Kings (CLICK) - tasked by the city with redeveloping the Yard, hoped for a "Big Fix" - inviting a small number of large manufacturers to set up shop in Brooklyn. But the few who accepted the invitation could not replace the thousands of lost jobs without subsidies or long-term government contracts [15]. In the end, even those weren't enough. At its nadir in 1985, the Yard had fewer than 30 businesses employing not more than 1,000 workers. The once bustling facility fell deeper and deeper into disuse and disrepair, and the surrounding community suffered with it.

The Yard's fortunes began to turn around in the late 1990s. In 1999, a new tenant, Steiner Studios, pledged $\$ 100$ million in private funding, to go along with the City's investment of another \$28 million, to build a state-of-the-art sound stage and associated infrastructure. The city continued to work to restore the Yard's rotting infrastructure, including tearing down dilapidated industrial buildings, and replacing inadequate electrical and sewage systems.

The Brooklyn Navy Yard Development Corporation (BNYDC), which replaced CLICK in 1981, broke up the large plots and welcomed small, light industrial businesses with few alternatives for affordable space in New York City. The Navy Yard's four million square feet of usable space have been made available to local industry, at a much lower cost than comparable properties in Manhattan. And price isn't the only consideration. According to one article, "[b] usinesses that could rent cheaper real estate on Long Island or in New Jersey pay the Brooklyn premium because owners want to work near their homes and clients and other like-minded entrepreneurs" [16].

The Yard weathered the Great Recession in part because of its diversified portfolio of business. It has a healthy mix of small, medium, and large firms seventy percent with less than five employees, twenty-five percent with over fifty, and only five percent with over three hundred [14] — and "is in the midst of its largest expansion since World War II" - adding roughly 1.8 million square feet of industrial space [15].

Andrew Kimball, President and CEO of BNYDC, has big plans for the future. He sees the Brooklyn Navy Yard as part of New York's evolving "Tech Triangle" - the "ribbon' of industry down the Brooklyn Waterfront" [17]. With a waiting listing of over one hundred businesses, Kimball is looking to double the active 
square footage available by 2022 . He would like to see employment at the Yard double over that period of time as well. If Kimball and his partners are successful, they will certainly have lived up to BNYDC's new slogan: "We Used to Launch Ships, Now We Launch Businesses" [14].

\section{Conclusion}

The point of this excursion into the past is to provide some perspective for the present and the future. When people predict that military spending cuts will have horrific economic effects, this paper has attempted to document a more complicated reality.

The several transitions away from war and toward peace have not been uniformly ruinous, though they have been painful for those directly affected. And a few places haven't entirely recovered, but it isn't clear that that is a function primarily of the loss of military jobs. There might be other reasons why Limestone, Maine, and Buffalo, New York, for example, are less desirable places to work and live than they were 50 or 100 years ago.

Looking ahead, we should anticipate that the evolving security environment and an era of relative fiscal austerity will result in lower defence spending, and additional consolidation of defence facilities, both public and private. Communities facing such consolidation should look to the experiences of the recent past, and the distant past, and fashion policies that can most efficiently convert underutilized facilities to productive ends.

\section{References}

[1] Fuller, S.S. The U.S. economic impact of approved and projected DOD spending reductions on equipment in 2013: summary of research findings, 24 October 2011, House Committee on Armed Services. http://armedservices.house.gov/index.cfm/files/serve?File id=33a3bd4efcaa-4eef-bea6-12bd39265f9a

[2] Barro, R. \& de Rugy, V. Defense Spending and the Economy, Mercatus Center: Arlington, VA, 2013.

[3] Zycher, B. Economic Effects of Reductions in Defense Expenditures, Cato Institute: Washington, DC, 2012.

[4] Bastiat, F. The Demobilization. Selected Essays on Political Economy, trans. S. Cain, ed. G. B. de Huszar, Foundation for Economic Education: Irvington-on-Hudson, http://oll.libertyfund.org/title/956/35425, 1995.

[5] Henderson, D.R. The U.S. postwar miracle. Working paper 10-67, Mercatus Center, George Mason University, 2010.

[6] Powers, P. Interview, Austin, Texas, 19 November 2013.

[7] Ladendorf, K. Airline executive favors Bergstrom, Austin AmericanStatesman, 1 February 1990.

[8] Ragsdale, K.B. Austin, Cleared for Takeoff: Aviators, Businessmen, and the Growth of an American City, University of Texas Press: Austin, TX, Kindle edition, loc. 114, 2004. 
[9] Ladendorf, K. Interview, Austin, Texas, 18 November 2013.

[10] Kinnane, A. DuPont: From the Banks of the Brandywine to Miracles of Science, E.I. du Pont de Nemours and Company: Wilmington, DE, pp. 3-7, 2002.

[11] Lammot's discovery allowed DuPont to make powder with sodium nitrate in place of potassium nitrate. Hounshell, D.A. \& Smith, J.K., Jr., Science and Corporate Strategy: DuPont R\&D, 1902-1980, Cambridge University Press: Cambridge and New York, p. 2, 1988.

[12] DuPont research and development, E. I. du Pont de Nemours and Company. http://www.dupont.com/corporate-functions/our-approach/science/scienceand-technology.html

[13] DuPont, Fortune 500 2014, http://fortune.com/fortune500/e-i-du-pont-denemours-and-company-86/

[14] Kimball, A.H. \& Romano, D. Reinventing the Brooklyn Navy Yard: A national model for sustainable urban industrial job creation. Proc. of the $1^{\text {st }}$ Int. Conf. on Defence Sites Heritage and Future, Portsmouth, UK, June 68, 2012.

[15] Brooklyn Navy Yard Center, The Brooklyn Navy Yard: Past, Present and Future, Brooklyn Navy Yard Development Corporation: New York, p. 21, 2012.

[16] Davidson, J. A place to make things: Preserving the Brooklyn Yard isn't just about restoring the buildings. New York, 6 August 2012.

[17] Blanchfield, C. Urban industry redefined: The Brooklyn Navy Yard. Urban Omnibus, 19 September 2012. 